\title{
MUSIC AND DEMOCRACY: \\ A TALE OF NATURE AND CONTRIVANCE
}

Chukwuemenam E. Umezinwa

\section{Abstract}

Regarding music and democracy, one is likely to ask: what has a goldfish in common with the canary? Or what has Athens got to do with Jerusalem? In grouping the disciplines according to university curriculum of studies, music is the queen of the arts while democracy as a system of governance has a better footing in the social sciences. Without prejudice to whatever we hold dear concerning these two conceptual entities, this article casts more than a cursory glance at the two, to find out if there are truths that might be of interest while we advance the cause of each. The starting point is to consider the nature of their origins, their purposes and the experiences they nurture. The findings are revealing. Music is as old as man and so, assumes the status of a necessary human good. Democracy as a recent human invention and being fraught with an endemic pursuit of selfish interests of individuals and nations, can, at its best, be a necessary evil. But, even the realization of this deficient best is as elusive as the concept which refuses to mean one thing as it is practised from nation to nation.

\section{Introduction}

There have been observed attempts by organizers of academic conferences and seminars to impress it on all who care to know and listen that music has a part to play in the survival and sustenance of democracy in Nigeria. How they make that connection is often a matter of semantics, sophistry and outright casuistry rather than through reasons born out of due considerations for subject matters of music and democracy. There is therefore, the danger of turning what could, at best, go for an ancillary role of music into music's 
principal task. Less frequent, however, do we see the reversal of roles where the survival of music depends on democracy. And this is the curious point which warranted the investigation into the origin and nature of music and democracy.

\section{Music as a Universal Phenomenon}

This article does not focus on the competing conceptions and definitions of music that exist. The understanding of the humanly organized patterns of sound in singing, dancing and playing will suffice. This arrangement of patterns of musical sound differs from place to place, culture to culture. This means that it is possible that what is regarded as music in one place may not be regarded as such in another. Different myths of origin exist in the musical history of various cultures. So, the origin of music is even shrouded in obscurity because it is safer to assume that it is as old as man. The earliest mention of music in the Judaeo-Christian Bible is in the reference to Jubal as the father of all that play the lyre (Gen. 4: 21). Music in the absolute sense of it was already in existence in the 'spheres' before the arrival of man. Most cultures attribute the origin of music to gods because of its experienced power on human emotions and social cohesion. A cursory look at some different musical cultures reveals the infinity of the musical art. The spread of Western musical styles and scales have always accompanied the ideological spread of Western culture through colonization, Christian evangelization, trade, technology, and education. This has left many Westerners and the non-Western peoples, whose cultures are invaded, with an erroneous impression. That impression is that music as a term refers only to Western music; that formal study of music in schools has to mean the study of Western musical culture. But we know that many cultures like the Gamelan, Java, Jewish, Indian and North American have musics that thoroughly satisfy the traditional, social, religious, aesthetic, educational, metaphysical and psychological needs of the culture more than the acquired sense of Western music, which is severely limited in the performance of the musics that matter to these cultures. According to Wright (1996) the music of the West has only permeated the eastern and western parts of the world but this does not mean that the peoples of the world have all been affected by it. In fact, the truth is that more people in the world are still glued to their musical traditions than are usually acknowledged. He states in no equivocal terms that:

...the music of the West, both classical and popular, is by no means the only music of the world. Great masses of people remain wholly or mostly unaffected by it.... China with a quarter of the world's people, India, with 800 (now 1.4 billion) million citizens, and Indonesia, the fourth most populous nation on earth, with 200 million inhabitants, all retain their native musical traditions independent of the West, as do the tribes of sub-Saharan Africa. The sounds of each of these cultures are radically different from each other, just as they are all unrelated to the music of Bach, Mozart and Beethoven. (p.408)

The attempt to expose the music of other cultures is nothing but to show that music is related to culture by which it is identified. Music relates to a place or people or event or class. This identity is not limited to a geographical location. Igbo music, by the same logic, has its own identity. This identity even in its various genres remains a permanent element that hinges on its intrinsic ability to defend, not itself but the Igbo people through whom it reveals itself as a "circumperinviving" being.

\section{Some Musical Cultures}

Jewish Music: Jewish music dates back to thousands of years. It has both religious and social character. What we have as Jewish 
music today has been traced to three separate sources: the Ashkenazi which refers to the tradition that came from Eastern Europe like the Klezmer. The second source is the Sephardic tradition which includes music from the Mediterranean areas and from Spain, North Africa, Greece and Turkey. The last tradition is the Mizrahi which came from the different Arabic cultures that haboured the Diasporas. The music of the Synagogue was cantorial in nature. There was the Temple music which has lasted from biblical times to the present. The liturgical music called the Piyyut is a poem with definite forms and usually written in Hebrew or Aramaic. The Adon Olam (Master of the world) which is attributed to one Solomom Ibn Gabirol of the $13^{\text {th }}$ century Spain and the Yigdal (May God be hallowed), are very popular examples. The Yigdal is based on the thirteen Principles of Faith developed by Moses Maimonides. These are used when saying the Shema Israel or putting on of the Tefillin in the morning. The Zemirot are hymns derived from the compositions of Rabbis of the Middle Ages and are sung on specific days and holidays. The Nigun are songs that are vocal and instrumental, which are performed by individuals or groups. They are considered meditative and transcending (both syllables and sounds). The Pizmonim are traditional Jewish songs of praise to God used for religious rituals and ceremonies such as prayers, circumcisions, and marriages. The Baqashot are hymns that are associated with the Diaspora Jews from Spain, used for keeping vigil, especially in the winter months. They were preserved among the initiates of the Kabbala. Israeli music has borrowed a lot of elements from around one hundred and twenty countries of the Diasporas, making the land of Israel a melting pot of musical cultures. There are the secular music called the Klezmer, Sephardic, Mizrahi and other folk versions that are accompanied with a lot of dancing.

\section{Indian Music}

India is about 1.1 billion people. That means that about one of every five people on earth is Indian. It has a third of the size of the U. S. It has 15 major languages and many regional dialects. It has a history that dates back to over five thousand years. The many jungles, deserts, and the towering Himalayas with peaks of 29,000 feet, all provide natural boundaries for the country. But these have not protected it from influences from other cultures over the centuries. Starting with the Islamic conquests of the $12^{\text {th }}$ century to the $18^{\text {th }}-20^{\text {th }}$ century colonization by the British, India has been able to form a definitive cultural synthesis which is characteristically its own. This culture has a well known religious and artistic root. The four Vedas (oldest religious literature in the world) are said to have been written around 1200 B.C. The Upanishads (or Forest Books) are rich religious and philosophical thoughts which have kept fascinating Western thinkers. The ancient yoga, which is a mystical, physical and mental discipline and Mahatma Gandhi are products of this rich heritage. Music is at home in India. From the mendicant to the snake charmer, from the radio/TV to the largest movie industry in the world, Bollywood, which is the highest promoter of Indian music and culture, the music of India is worth studying.

Indian music has various classifications and variations of folk, popular, classical music. India has multi-cultural currents as well as many ethnic groups. The result is, therefore, a wide range of religious, socio-cultural and entertainment music. Two forms of South Indian classical music which date back to the $13^{\text {th }}$ century are distinguished. They are the Karnataka Sangeeta or in English as Carnatic (the name derives from the carnatic plateau) and Hindustani music which some traditions trace to a common Vedic origin. The Carnatic classical music belongs to the South whereas the Hindustani classical belongs to the North. The Vedas have a very sublime regard for the chanting of the mantra. Thus according 
to the Baghavad-gita, by Prabhupada, (1986) "if anyone quits his body at the end of life chanting Hare Krsna... Hare Rama... he certainly reaches one of the spiritual planets, according to the mode of his practice" (p.428). Carnatic music has over 2,500 years of tradition and it is completely melodic vocal. Carnatic music is based on two principal elements - raga - the melodic formulae and tala, the rhythmic cycles. Indian Folk music has variants of the Bhaageete, a devotional song type, the Bhangra, which is a pop style of folk dance. The Lavani is a folk usually associated with women. The Dandiya has equally been popularized from its dance-oriented folk root. The Rajasthan refers to a collection of multi-cultural songs that have won great respect in Bollywood (Indian Movie Industry) due to its ancient and original flavour. The Bauls of Bengal are mystical musicians who took their name from the Sanskrit word batul, which means divinely inspired insanity. One of the greatest names in Indian music is Rabindranath Tagore, who wrote over two thousand songs that have come to be known as Rabindra sangeet. It has assumed the status of a tradition of its own. The Qawwali is a Sufi type of devotional music which is derived from the Hindustani classical. The arrangement usually features lead singers and chorus.

Indian musical texture has generally three layers - the background drone, the melody and the rhythm/percussion. In the melodic layer, the singer is usually accompanied by an instrument, say a violin. This instrument plays along with the singer, echoes and supports or responds to improvisations. The Sruti layer (pronounced shroo-tee) has one or more specialized instruments, like the tambura (a four-stringed plucked instrument). It creates a buzzing timbre, a steady tone that makes overtones. This is the most recognizable "Indian" sound. The percussion layer has the mridangan drum as the principal instrument of Carnatic music. Other percussion instruments include the ghatam (a large clay pot with a ringing, metallic sound), the kanjira (a tambourine with a snakeskin head and jangles made of coins) and a morsang (a Jew's harp, which plays the same thing with the other percussion instruments.

Raga: the melodic system is defined by ancient literature as "that which colors the mind". Raga is an embodiment of a musical personality. It is an expressive entity. Raga has to speak to the heart, feelings and emotions of humans. It has different sets of rules concerning the singing of notes, ornamentations and sliding notes and so on. Ragas are associated with the ten traditional human emotions (or rasas): love, sadness, heroism, anger, fear, disgust, wonder, laughter, religious devotion, peacefulness). Other associations with animals, deities, colors, seasons of the year, time of the day and with other magical qualities like healing, calming the mind and creating warmth were common. "The notes of raga move constantly in various degrees of dissonance and consonance against the unchanging background of a tonal center and perfect fifth".

The Melakarta System is the system of scales in Carnatic music. It has about 72 generative scales (the arrangement of pitch in a sequence of ascending or descending order). The do, re, $\mathrm{mi}, \mathrm{fa}$, so, la, ti become sa, ri, ga, ma, pa, da, ni. The sa and pa (first and fifth) are fixed drone notes. Other notes have two or three variations or pitches within which they mutate to form a particular scale. Some of the scales might sound familiar but others will sound very uncommon to us. The Tala is the organization of time in music. It is the time cycle. It encompasses the shortest conception of time to infinity. Beats are grouped into regularly occurring cycles called talas. In theory, ther are hundreds of them but today, Carnatic music has four talas: adi tala (8beats), rupaka tala (3 beats), khanda chapu tala ( 5 beats), misra chapu tala (7 beats).

\section{Japanese Music}

Japan has received a huge chunk of its tradition from the outside. The language is from China and the religion, Buddhism, is 
from India. Yet the traditional music of Japan has remained intact. Traditional music here refer to the pre-Meiji Japan (1868-1911).

\section{General Characteristics of the Traditional Music of Japan Pitches and Scales:}

We are used to the Western scale of music in which an octave is equally divided among twelve tones of equal temperament. For this reason, it is easy to transpose one piece from one key to another without affecting the melodic interval or the notes of the music. The equal-tempered scale of Western music replaced the earlier Pythagorean scale which was based on the pitches from strings that vibrate in small ratios $(1: 2,2: 3,3: 4$ e.t.c).

Greek music made extensive use of modes which assumed different names at different periods in history. The oldest harps and shepherd pipes are believed to have had seven tones to which the Greeks assigned the names of the first seven letters of the alphabet. A was the lowest key. But with the passage of time, Greek notation became very complicated with the modal scale. Pope Gregory the Great (540-604) changed Church notation again by using the first seven letters showing the lower octave by capitals and the upper by small letters. Notes were added to the lower $A$ later and when in the $16^{\text {th }}$ century, modern scale was adopted; C instead of A had become the lowest note. One of the proofs that show the influence of Asian music on the Greek tradition is the use of intervals smaller than semitone. Greek music was melodic. It was this tradition that gave birth to many musical terms that are used today - tonic, diatonic, melody and so on. It was equally the tradition that prepared the stage for the medieval and modern acoustics by providing the mathematical basis of musical sound. The accidental birth of the opera is traced back to the mistaken belief that Greek drama was entirely sung. It was Greek music that gave us the modes.

The first modes were those of $\mathrm{A}$ and $\mathrm{C}$ - called Aeolian and
Ionian modes respectively.

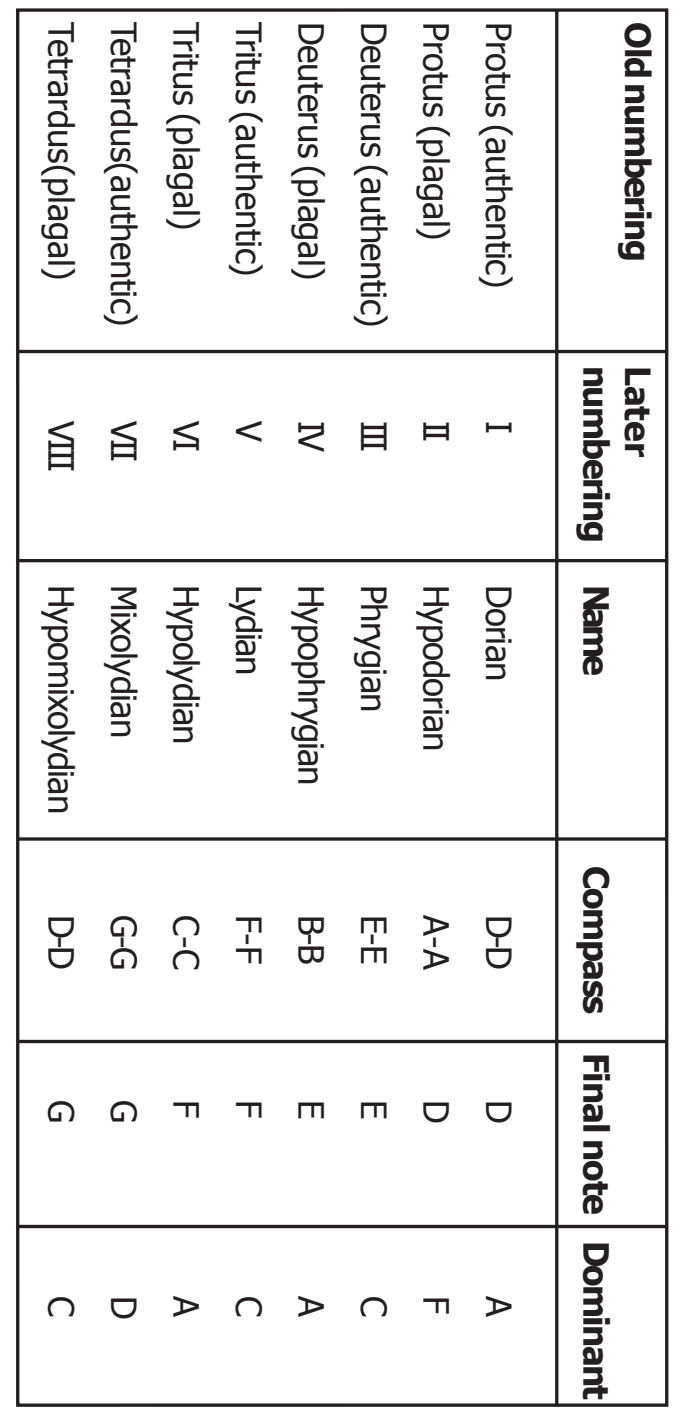




\begin{tabular}{|c|l|c|c|l|}
\hline Numbering & Name & Compass & Final Note & Dominant \\
\hline IX & Aeolian & A-A & A & E \\
X & Hypoaeolian & E-E & A & C \\
XI & Ionian & C-C & C & G \\
XII & Hypoionian & G-G & C & E \\
\hline
\end{tabular}

Yoruba music is well known worldwide. It has greatly influenced the music of the black African Diasporas in the Caribbean, Cuban and Brazilian cultures. But the home of the Yoruba is in present day Nigeria where they are located in the Southwest. There are equally Yoruba-speaking people in Togo and Benin Republics. The role of their dundun in their highly sophisticated drumming culture is generally acknowledged. Like most Nigerian tribes, their drummers 'talk' using the drums and people understand. This is done by imitating the linguistic tonality and by consolidating the long tradition of phonic interpretation of the language. Major instruments of the Yoruba music include agbe,(shaker), ashiko (cone shaped drum), dundun (two types of big and small drums called the iya ilu and omole), goje (a type of violin like the Sahelian Kora), sekere (a melodic shaker; beads or cowrie shell well twigged around a gourd), agidigbo (a type of thumb piano), bembe (a type of band bass drum), bata, (a well decorated drum of many tones), gudugudu (a smaller melodic bata), sakara (goat skin stretched over a clay ring to make a percussive drum), agogo (a high-pitched clapperless bell or type of tuning fork), sawaro,(low-pitched type of agogo), aro (much like sawaro), gbedu (another name for dundun or iya ilu), seli ( a combination of aro, sawaro and hand-clapping).

Hausa music belongs to the Hausa people found mainly in the Northern part of Nigeria. It has contributed the lovely one-stringed fiddle called goje to the national instruments. Hausa music is generally divided into rural folk and court music. Hausa music does not, on face value, have the wide variations and sophistication that are easily identified with Igbo and Yoruba music. The Hausa value their ceremonial music called rokon fada which is performed as a status symbol. Such music is played on festivals and coronation of an emir or even on Thursday evenings when the emir demonstrates his authority during the sara. There are courtly praise singers who chant in adulation of the emir's achievements. Instruments of royalty like the kettledrums, talking drums and the famous kakaki are used on such occasions. The kakaki is traced to the old Songhai Empire. In rural areas, young girls perform the asauwara dance and the bori cult music.

\section{Democracy and Illusion}

Today, certain things are assumed a priori about democracy. It has been dubbed the government of the people, for the people and by the people in the tradition of Abraham Lincoln's definition. It has been called the best form of governance. It is taken to be the form of government befitting for civilized nations and government for the survival of the free market.

\section{Democracy and Nigeria in the Last Ten years (1999 to 2009)}

These ten years have become the longest unbroken era of civil rule in Nigeria. The years under study were described by the last president as years of reform. This was at a time when Nigerians were looking at Chief Obasanjo as a messiah sent from the gates of a near-hell-experience to redeem the staggering nation. A reform is defined by the Oxford Advanced Learner's dictionary as change that is made to a social system, and organization, etc. in order to improve or correct it. The nature of such a reform is dictated by the policies, bills and acts of those who preside over the affairs of society or the organization in question. The dictionary definition does not equivocate in highlighting the direction of the reform. This means that in a nation state like Nigeria, a reform could head the direction 
of education or health or election or the economy. The onerous responsibility that goes with every reform is that it should not compromise conformity to the standards and parameters that are deemed acceptable. Thus the essence of every reform is to correct or improve on the status quo. Otherwise the reform is unnecessary.

Casting a wild glance across the activities of president Obasanjo, one is left with a complex of impressions regarding the direction of his reforms. When he took over in May 1999, his inaugural address was the unassuming message of an experienced statesman who was poised to defend the constitution of the nation as well as stamp out corruption in public offices through transparency and accountability. Nearly eight years in office, Obasanjo adopted a vision 2020 slogan. The editorial of, the Daily Sun, April 10 reports Obasanjo as saying:

We have identified a few things we are doing rightly now... we have to deepen and widen them and continue to do them rightly as there will be no going Back... if we take it as a slogan and work towards it in all sectors, we are surely going to get there (2006:8).

Obasanjo kept sounding like a man who was the captain of a rudderless ship and all of a sudden, discovered his bearing. We are referring to a vision that is eleven years away in a nation that is characterized by regime- change-policy-change as an attitude to national development and planning. Suppose this agenda was accepted by Nigerians, where was the socio-ethical content and philosophy to guarantee it? All of this equals the foiled grand plot to stay back in power about which the president remained taciturn for long until his dream was killed by the Nnamani-led senate. Nigerians are all very familiar with sloganeering and the politics of self-succession or transformation. The unfolding of a reform agenda in the evening of his regime's life was a whimsical rehearsal of a tragi-comedy. This government established the National Economic Empowerment and Development Strategy (NEEDS). It was intended to curb mass unemployment, abysmal decay of physical and social infrastructure, weak manufacturing capacity, archaic agricultural practices with an ageing farming population among other ills plaguing the national life. Nigerians were in doubt whether these would ever be realized.

A reform is supposed to be an agenda with a general philosophy discernible in every government office and parastatal. The isolated cases of visible hard work in, say the banking sector, and NAFDAC or the National Maritime Authorities, should not confuse the issue here. The credits coming from these few angles cannot be identified as a reform agenda.

Nigerians would have had it better if the Obasanjo regime had not toyed with the expectations of the masses and great the great confidence reposed on it on ascension of office. The first form of reform, which the president undertook, was to globe-trot in the name of re-making the international image of the country. For this same reason the president was outside the country for 365 days in the first four years in office. It was a huge investment in a pathological idiosyncratic drive. Many years after that, the image of this country is yet to change abroad. But why work on image instead of reality? Why did the regime revert to chasing shadows instead of correcting the object creating the shadows? Nigerians have enough dose of common sense to know that if we are good, our image will definitely be good. But in Obasanjo we saw a man trapped in his delusions and illusions and who alone thought he knew what was good for us all. Today, the Federal Ministry of Information and Communication has launched a second round of the wild goose chase termed 'the re-branding of Nigeria' with the support of the ailing president Yar' Adua. This investment in illusion has been roundly criticized by many Nigerians. The truth is that for many of us, Nigeria is such a bad product that mere media re-branding cannot make it sell. Changing 
the product appears a better task.

Prince Charles Dickson's description of the Obasanjo led leadership was simply inventive. Niger Delta has been burning, Maiduguri, Gombe and Bauchi witnessed riots and tomorrow it will snowball into Anambra State as a reprisal while large mouthed confusers-in-chief, Fani Kayode and Remi Ojo brazenly said the untrue and the irrational in the name of what the President would like to hear. (cf. Daily Sun, April 19, 2006:9).

How on earth did a regime, which lacked credibility, embark on a serious reform? So much noise was made about the nation's indebtedness but not once did this regime look in the direction of those who borrowed the money from the Breton Woods institutions (the World Bank and the IMF) or what was done with the said borrowed money. Again during the reconciliation Panel sitting across the nation, the Oputa-led panel invited among others, Generals Ibrahim Babangida and Mohamadu Buhari but they flatly refused to put up appearances. Nothing happened. Which sort of reform would gloss over the flagrant flouting of court and commission fiats were it not the case that certain campaigns are simply political windowdressing? Of course, years after the conclusion of the tasking exercise, the Obasanjo administration not only failed to implement the recommendation of the Oputa- panel but went ahead with executive neglect of court orders prompting, the National Executive Council (NEC) of the Nigerian Bar Association (NBA) to reach a resolution bordering on a strike action. It was February 22-24, 2006. And on the $13^{\text {th }}$ and $14^{\text {th }}$ days of March, a nationwide boycott of courts took place, to protest the flagrant disregard and disobedience of court orders by the executive arm of government. The judgments of Court to return the security aides of the then governor of Anambra State Dr. Chris Ngige, the recall of assemblymen who lost at the different tribunals were some examples of rulings that went unheeded.
In the education sector, it was another sorry story. One upon a time, the minister of education, Mrs. Chinwe Nora Obaji said government was going to slow down on the rate of granting licenses to new universities. What followed was a reversal of this position as Obasanjo himself announced that Federal Government would license an additional seventy - five State and Private Universities in the country bringing the total to one hundred and fifty (150). Citing his reason that the existing ones are not living up to expectation, one would have expected the Government to work hard to strengthen the existing universities against the perennial woes: dearth of lecturers, insufficient government funding non-availability of research grants, poor infrastructure and accommodation among others. But the government took a "better" decision. For Obasanjo to make such pronouncement on the heels of the complaint from the NUC that there was a severe shortage of manpower in the universities is to prove a suspicion - there was no reform agenda for Nigerian education under Obasanjo. The spate of politically motivated killing in Nigeria under Obasanjo baffled the citizenry. The late attorney general, Bola Ige, Harry Marshall, Dikibo and a long list of others were murdered in that regime. No tangible arrests or government commitment was recorded.

By the last count, 10,000 of Nigeria's 35,000 registered medical doctors had as at July 2003 left the country in search of greener pasture in other nations. This is bad news from the health sector. That number must have doubled by now. Many other professionals lost confidence in the ability of the nation to cope with her numerous problems. The result is brain drain.

The prices of oil products, petrol, kerosene, gasoline headed north in a country rated the sixth oil producing nation of the world. The economic power of the masses went very low whereas the market forces were driving prices skywards. Deregulation, privatization, and monetization became magic wands for government 
in confusing the unsuspecting masses. These exercises were fraught with huge fraud and an unwholesome mercantilism fuelled by official greed. There was great scam in the oil sector. The audit of the transactions between the oil firms and the CBN produced a scent of corruption choking the life of the nation. The EFCC became a mad dog easily turned loose on any perceived opponent of the Obasanjo administration or any challenger of the third term ambition. It was the same story in every sector.

\section{Rethinking Democracy}

The word, 'democracy' does not mean any one unambiguous thing, at least in the mind of its users. According to Macpherson, "the word has changed its meaning more than once, and in more than one direction". (1982:1). Democracy used to be a very bad thing. About one hundred and thirty years ago, nobody wanted democracy because of its fatal posture to individual freedom. Very intelligent minds opposed all the ideals of democracy. Then, after the First World War, the allied powers of the West claimed that the war was fought to make the world safer for democracy. This caused a major shift in the use and understanding of the word.

The Russian revolution of 1917 was a clear statement against democracy and all it stood for, at least as long as the Communist state lasted. Democracy as understood or practiced among other nations is greatly nuanced. Many nations achieved independence under circumstances that ensured the survival of one-party system as the real form of government. China is not a democracy. Yet it is almost ruling the world in trade, production and economic and technological agility. Singapore is not a democracy, but it has become the envy of other nations in the economic power and peace it enjoys. In Russia, a unique form of democracy allowed the last Prime Minister, Vladmir Putin, to merely hand-pick his successor, Medvedev. In Nigeria, office holders are merely foisted on the people with or without their consent. It is even orchestrated through the official organs of government - INEC, Police, Army and so on. In the West where liberal democracy becomes the natural ally to capitalism, democracy assumes an added dimension. The concept is therefore fluid, taking the shape of its container. Two changes are usually said to be responsible for the shifts in the meaning of democracy. First, in the West, democracy arrived after the states had been liberalized and needed it to be liberalized if it was to survive the tenets of individualist, competitive market economy. The second thing was that democracy meant to give voice to the poor. The few rich, powerful and intelligent people became afraid of concentrating power in the hands of the poor majority.

The tale of democracy is the tale of a human contrivance. The United States and the nations of the British Commonwealth began to arrogate to themselves the description 'democratic' and to create the erroneous impression that development and economic well-being of nations are inextricably tied to the democratic system. This false thesis has not only imbued the system with inherent powers it does not have, but also deceived poor nations into an ideological orientation that makes it impossible to apply the brakes in their march to making democracy a prerequisite for the blossoming of free market economy.

\section{Conclusion}

Whereas music is a natural human good, democracy is but one of the cleverest inventions of modern man. It is not, therefore, a natural thing to man. Love of music is natural but love of democracy is acquired. The major confusion which may easily arise is that between politics and democracy. But politics is much older than democracy and in fact, man has been described as a political animal. The need to organize human society (politics) presumes a population. And before any such population ever formed, music was already 
present. Whereas politics may be a closer estimate in time, democracy is not. The virtues of democracy are virtual not actual. The posture of democracy as a system with automatic mechanisms for transforming peoples and nations is nothing but propaganda. Every system of governance is as good as the individuals that run it. The subject matters of the two are different. The only common denominator is that both music and democracy are at the service of the human person. But in relation to role, music could serve a role in democratic regimes just the way that democracy can create conditions that promote the art.

\section{References}

Macpherson, C. B. (1982). The real World of Democracy New York: Oxford University Press

Wetsrup, J. A. \& Harrison, F. (1960). The New College Encyclopedia of Music, New York: W. W Norton

Wright, C. (1996). Listening to Music (2 ${ }^{\text {nd }}$ ed..) Minnesota: West Publishing Company

www. wikkipedia.com 